\title{
Seasonal benthic microbial activity in the southern North Sea; oxygen uptake and sulphate reduction
}

\author{
A. C. Upton ${ }^{1, *}$, D. B. Nedwell ${ }^{1, * *}$, R. J. Parkes ${ }^{2}$, S. M. Harvey ${ }^{3}$ \\ ${ }^{1}$ University of Essex, Department of Biology, Wivenhoe Park, Colchester, Essex CO4 3SQ, United Kingdom \\ ${ }^{2}$ University of Bristol, Department of Geology, Will's Memorial Building, Queen's Road, Bristol BS8 1RJ, United Kingdom \\ ${ }^{3}$ Dunstaffnage Marine Laboratory, PO Box 3, Oban, Argyll PA34 4AD, United Kingdom
}

\begin{abstract}
From an initial cruise, 6 sites were selected from the 41 sampled to be representative of the major types of sediment in the southern North Sea. The 6 sites in the mixed, frontal and stratified areas of the southern half of the North Sea exhibited a wide range of environmental conditions, particularly sediment type, water depth and organic matter content. Benthic microbial activity, and its seasonal variability, were determined at bimonthly intervals from September 1988 to September 1989. The significance of aerobic and anaerobic respiration in the degradation of organic carbon was investigated by measuring the rate of oxygen uptake and sulphate reduction for each sediment. All sites showed significant rates of oxygen uptake (range 5.3 to $27.8 \mathrm{mmol} \mathrm{O}_{2} \mathrm{~m}^{-2} \mathrm{~d}^{-1}$ ) and sulphate reduction (range

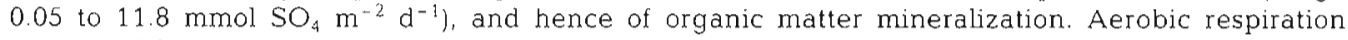
accounted for between 47 and $89 \%$ of annual organic matter degradation depending on the site, the balance being due to anaerobic sulphate reduction. Benthic mineralisation rates were greatest at a station near the Dogger Bank and one near the Dutch/Belgian coast. However, benthic mineralisation as a proportion of the net annual primary production in the water column was higher at stratified stations in the central North Sea (average $47 \%$ ) than in the more southerly stations with mixed water columns (average $26 \%$ ). Estimates of benthic organic mineralisation were used to calculate the magnitude of total benthic mineralisation in the southern half of the North Sea and compared to estimates of net primary production for the same area. On the average, for the whole of the southern North Sea, benthic mineralisation was equivalent to $17-45 \%$ of the total net primary production. These results demonstrate that the bottom sediments are important sites of organic degradation in the North Sea system.
\end{abstract}

\section{INTRODUCTION}

In aquatic systems degradation of primary and secondary biomass can occur in the water column, or on and in the bottom sediments when organic detritus settles from the water column (Nedwell 1984). The relative importance of the bottom sediments in organic mineralisation will depend in part upon the depth of the water column as, other things being equal, the shallower the water column the more organic material

\footnotetext{
- Present address: Marex Technology Ltd, Cowes, Isle of Wight PO31 7AW, UK

- Addressee for correspondence
}

will survive settlement through the water column and impact the bottom sediments. However, in shallow waters increased turbulence may diminish settlement rates, thus modifying the downward flux of material. In shallow coastal waters up to $50 \%$ of the organic matter production may be degraded in the bottom sediments (Jørgensen 1982, 1983).

Degradation of organic detritus in the sediment will result from the cumulative action of the benthic heterotrophic biota, both aerobic and anaerobic. Aerobic mineralisation is limited to the surficial layer of sediment into which oxygen penetrates; usually to only a few mm depth in most shallow water sediments (e.g. Revsbech et al. 1980). Below the aerobic layer organic 
matter will be mineralised by anaerobic microbial activity. In marine sediments sulphate reducing bacteria tend to be by far the most important group of anaerobes because of the abundant sulphate in seawater (Jørgensen 1980). Bioturbation increases the transport of organic matter from the sediment surface to deeper, anaerobic layers, and therefore tends to enhance the relative importance of sulphate reduction to total degradation of organic material (Berner \& Westrich 1985). In inshore marine sediments where organic input is relatively high, and where bioturbation may be significant, sulphate reduction can account for up to half of the total organic matter degradation (Jørgensen 1980, 1982, Parkes \& Buckingham 1986, Christensen 1989).

The present work was undertaken as part of the North Sea Community Research Programme of the Natural Environment Research Council (UK). The intention of the research programme was to develop understanding of the southern half of the North Sea where the water is shallow, generally $<50 \mathrm{~m}$. Therefore the bottom sediments potentially are very important in the budgets of organic degradation and nutrient recycling. Although measurements of benthic processes have been made in the North Sea (e.g Jørgensen \& Revsbech 1989, Jørgensen et al. 1990, van Raaphorst et al. 1990, 1992), these have tended to be either for a restricted period or at only 1 or 2 stations. The present work was intended to measure benthic processes at a number of stations covering the range of sedimentary types present in the southern bight of the North Sea, and to continue measurements at regular intervals so that the seasonal ranges of activities could be evaluated.

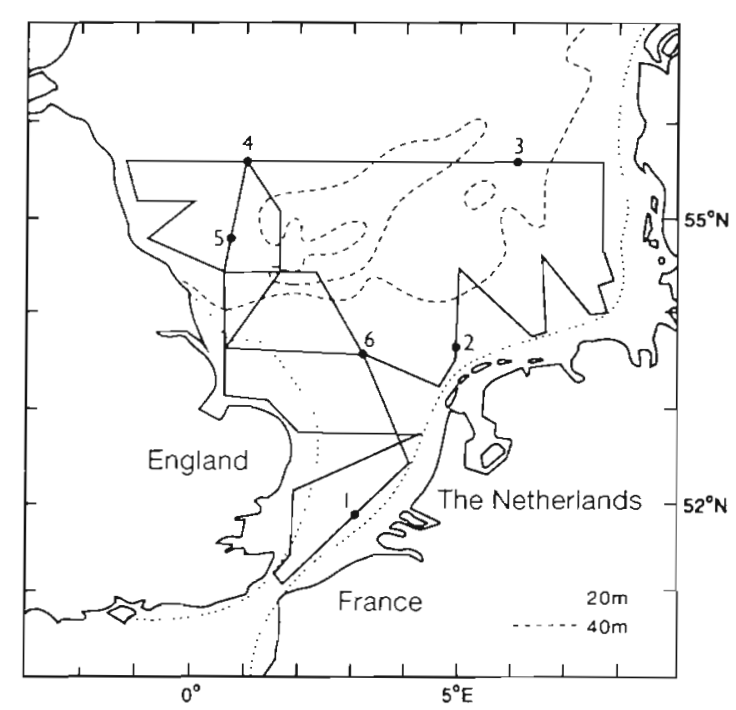

Fig. 1. Positions of the benthic sampling stations in relation to the North Sea survey track

\section{MATERIALS AND METHODS}

Sample sites. During April-May 1988, an initial survey cruise was made in RRS 'Challenger' along the standard cruise track of the NERC North Sea Programme. Forty-one benthic sites, evenly spaced along the cruise track, were sampled with a multicorer and samples of the 0 to $10 \mathrm{~cm}$ horizons taken for measurement of particle size distributions, organic content and sulphate reduction rates. On the basis of these initial data 6 sites were selected as representative of the sediments sampled during the initial cruise: Stn 1, $51^{\circ} 45.36^{\prime} \mathrm{N}, 02^{\circ} 59.96^{\prime} \mathrm{E}_{i} \operatorname{Stn} 2,53^{\circ} 37.10^{\prime} \mathrm{N}, 04^{\circ}$ $35.70^{\prime} E_{i} \operatorname{Stn} 3,55^{\circ} 30.00^{\prime} \mathrm{N}, 06^{\circ} 06.10^{\prime} \mathrm{E}_{i} \operatorname{Stn} 4,55^{\circ}$ $29.90^{\prime} \mathrm{N}, 00^{\circ} 54.50^{\prime} \mathrm{E}_{i} \operatorname{Stn} 5,54^{\circ} 39.16^{\prime} \mathrm{N}, 00^{\circ} 31.06^{\prime} \mathrm{E}_{\mathrm{i}}$ $\operatorname{Stn} 6,53^{\circ} 30.78^{\prime} \mathrm{N}, 02^{\circ} 59.33^{\prime} \mathrm{E}$ (Fig. 1). Stns 1, $2 \& 6$ were characteristic of the sandier sediments in the southernmost region of well-mixed water columns near the English Channel. Stns $2 \& 6$ also were near the position where a front develops in the water column during the summer. Stns $3,4 \& 5$ were characteristic of the more northerly muddy stations in the central region of the North Sea which stratify during summer. Water depths varied from 25 to $81 \mathrm{~m}$, with the deeper sites in the northern stratified part of the southern bight (Fig. 1, Table 1). The sites were sampled at approximately bimonthly intervals from September 1988 to September 1989 , returning to the position of each station as accurately as possible within the operating characteristics of the DECCA navigation system.

Sampling method. Undisturbed sediment cores, between 15 and $25 \mathrm{~cm}$ in length, were collected from the sites using a Multiple Corer (Barnett et al. 1984). Special core tubes (internal diameter $5.78 \mathrm{~cm}$ ) were developed to incorporate 2 sections that were joined with an outer perspex sleeve and sealed with ' $O$ ' rings. The lower section of each core tube (length $39.6 \mathrm{~cm}$ ), in which the sediment core was collected, was removed from the corer only when excess water in the upper section had been siphoned off. The upper portion of the lower section was accurately machined to enable insertion of, and effective sealing by, stirring heads for oxygen uptake measurements. Modification of the longer core tubes used by Barnett et al. (1984) was essential as these made extraction and accurate sectioning of the sediment difficult and were too long to enable effective mixing at the sediment water interface during flux measurements. The volume of water overlying the sediment was between 100 to $400 \mathrm{mI}$ in these modified cores. On average 20 cores were collected from each site per cruise, with 2 deployments of the corer.

Measurement and analyses of biological activity and sediment characteristics. Immediately after collection sediment cores were sealed top and bottom 
Table 1 Net annual oxygen uptake rate and sulphate reduction rate 10 to $20 \mathrm{~cm}$ depth) for the 6 sampling stations in the southern North Sea measured between September 1988 and September 1989

\begin{tabular}{|c|c|c|c|c|c|c|}
\hline \multirow[t]{2}{*}{ Stn } & \multicolumn{2}{|c|}{ Net annual rate ( $\left.\mathrm{mmol} \mathrm{m} \mathrm{m}^{-2} \mathrm{yr}^{-1}\right)$} & \multirow[t]{2}{*}{ Organic matter (\%) } & \multicolumn{2}{|c|}{ Particle size } & \multirow[t]{2}{*}{ Water depth (m) } \\
\hline & Oxygen & Sulphate & & $\%$ sand & silt/clay & \\
\hline 1 & 3236.3 & 173.3 & 0.29 & 97.7 & 2.2 & 31 \\
\hline 2 & 4583.9 & 699.2 & 0.65 & 97.5 & 2.3 & 25 \\
\hline 3 & 4392.2 & 556.3 & 2.93 & 71.0 & 28.8 & 52 \\
\hline 4 & 3771.7 & 349.8 & 1.88 & 86.7 & 13.3 & 81 \\
\hline 5 & 2836.1 & 205.4 & 0.99 & 96.4 & 3.6 & 63 \\
\hline 6 & 4451.5 & 1182.5 & 1.18 & 96.1 & 3.4 & 30 \\
\hline
\end{tabular}

with rubber bungs and placed in a cold room at the temperature of the water immediately overlying the sediment (i.e. the in situ temperature). At each site seawater (approximately 100 l) was collected from as close to the sea bed as possible with water sampling bottles on the CTD. This water was placed in a darkened PVC tank and aerated, circulated and cooled using a thermocirculator (Churchill Instruments Ltd, Uxbridge, UK), at the in situ temperature of that site. Nine sediment cores with their tops removed were carefully placed vertically in the tank, without disturbing the sediment, and incubated completely immersed for between 4 and $18 \mathrm{~h}$. This allowed the sediment to reequilibrate after coring before rates of oxygen uptake and sulphate reduction were measured. The length of the equilibration period depended on the time interval available between sampling stations. Measurements of the vertical profiles of the physical and chemical characteristics of the sediment were taken from the remaining cores as soon as possible. This was normally $<2$ h after sampling.

Oxygen uptake rates. Six of the intact equilibrated cores were used to measure the oxygen uptake at each site. The measurements were made according to the method and equipment of Parkes \& Buckingham (1986) with the cores incubated at the in situ temperature and in the dark. The tops of the core tubes were sealed with an electronic magnetic stirrer (Rank Brothers Ltd, Scientific Division, Cambridge, UK) which could be moved further into the core to compensate for sample removal. Enclosed water was sampled with a $10 \mathrm{ml}$ glass syringe for analysis of dissolved oxygen concentrations using an automated Winkler amperometric back-titration (Talling 1973; Mettler DL20 titrator, MSE, Crawley, UK). Water current velocity above the sediment can influence $\mathrm{O}_{2}$ uptake rates measured. To address this problem 2 different stirring speeds were used. Triplicate cores were stirred slowly at a rate (300 rpm) that ensured the main body of overlying water was fully mixed but no material was resuspended, while a further 3 cores were stirred at a faster rate that just suspended any fine flocculent material at the sediment surface without resuspending the sediment itself. The data from both treatments was averaged and thus the oxygen uptake data includes a measure of the effects of different near-sediment current velocities.

Three dissolved oxygen determinations were made from each core. The first was just prior to each core being sealed (time zero), the second at a midpoint time interval, and the third at the end of the incubation period. Oxygen uptake rate was calculated from the mean time zero value and the 12 measured dissolved oxygen concentrations. The length of each incubation period depended on the time available between sampling stations and the requirement not to allow oxygen depletion from the overlying seawater to exceed approximately $15 \%$ of air saturation. The incubation periods therefore varied from between 2 and $10 \mathrm{~h}$ depending on the site and the time of year.

As soon as the cores had been removed from the corer the overlying water from 1 core was siphoned into Winkler bottles ( $4 \times 125 \mathrm{ml}$ volume). Two were fixed immediately and 2 were incubated in the dark at the in situ temperature. These samples were fixed after a known time period and the dissolved oxygen concentration determined to measure the oxygen removal within the overlying water (Parkes \& Buckingham 1986).

Sulphate reduction rates. Three intact equilibrated cores were used to measure the sulphate reduction profile. Each core was extruded sequentially into a $5 \mathrm{~cm}$ collar, sectioned with an aluminium slice, and whilst being flushed with oxygen-free nitrogen (OFN) triplicate subsamples were taken with $5 \mathrm{ml}$ polypropylene hypodermic syringes with their needle ends removed. These were then sealed with butyl rubber Suba-Seals (Wm. Freeman \& Co. Ltd, Barnsley, UK). After equilibration for 2 to $6 \mathrm{~h}$ in OFN-flushed anaerobic jars at the in situ temperature these subcores were injected with $2 \mu \mathrm{Ci}\left(74 \mathrm{MBq}\right.$ ) of ${ }^{35} \mathrm{SO}_{4}$ (between 2 and $10 \mu \mathrm{l}$ was injected, depending on the specific activity) throughout the length of each sub-core. The samples were incubated under OFN at their in situ temperature for $24 \mathrm{~h}$. The samples were then frozen at $-20^{\circ} \mathrm{C}$ and 


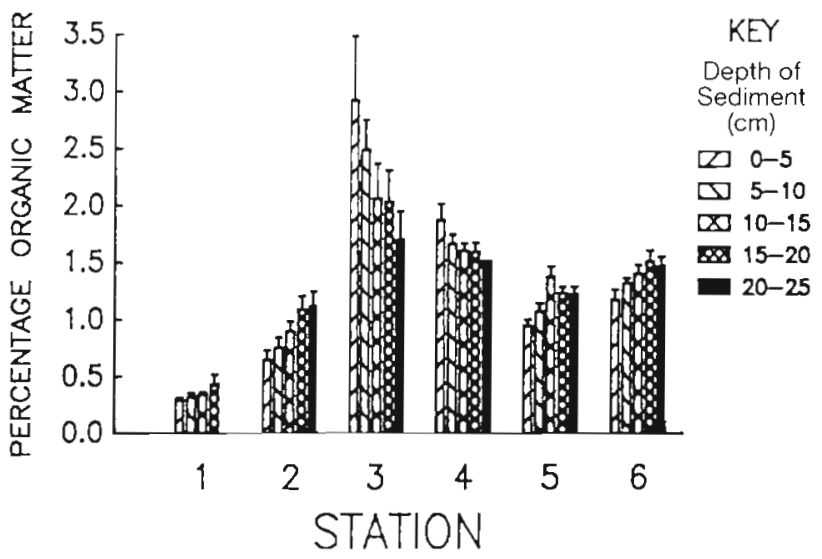

Fig. 2. Sedimentary orgaric contents (ash-free dry wt) for each station at $5 \mathrm{~cm}$ depth intervals, averaged for all cruises. Error bar $=1 \mathrm{SE}, \mathrm{n}=24$

stored for later analysis in anaerobic jars under OFN to prevent any sulphide reoxidation. Zero time blanks were precooled in a freezer (approximately $30 \mathrm{~min}$ ) prior to injection and immediately frozen under OFN at $-20^{\circ} \mathrm{C}$ after injection.

After return to the laboratory the samples were analysed for ${ }^{35} \mathrm{~S}$ in acid volatile sulphide (AVS) and pyrite plus elemental sulphur $\left[\mathrm{S}^{0}\right]$ (PVS) (Parkes \& Buckingham 1986). Sulphate reduction rates were calculated according to the method of Jørgensen (1978) after subtraction of any activity in the blanks.

Water and organic matter content. One core from each site was divided into $5 \mathrm{~cm}$ depth sections and $10 \mathrm{ml}$ from each stored frozen. The percentage water content was calculated by weight loss on freeze drying (Edwards High Vacuum, Crawley, UK). The percentage organic matter content was calculated as weight loss on heating aliquots of dried samples at $450^{\circ} \mathrm{C}$ overnight in a muffle furnace (Gallenkamp, Loughborough, UK).

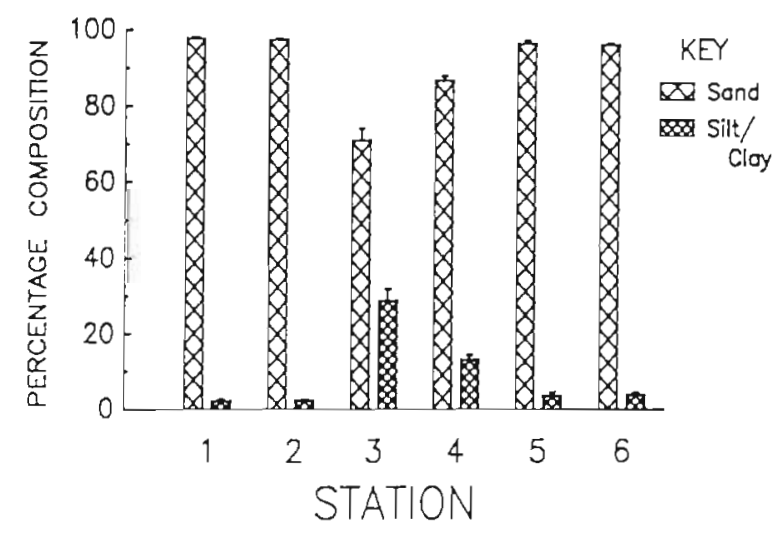

Fig. 3. Proportion of sand and silt/clay at each station, averaged for all cruises. Error bar $=1 \mathrm{SE}, \mathrm{n}=8$
Pore water analysis. One core from each site was sectioned and subsamples centrifuged $(2000 \times g$ for $10 \mathrm{~min}$ ) under OFN. The pore water was filtered (GF/F glass fibre filters; Whatman Ltd, Maidstone, UK) and aliquots $(4 \mathrm{ml})$ from each $5 \mathrm{~cm}$ section were added to zinc acetate $(1 \mathrm{ml}$ of $10 \% \mathrm{w} / \mathrm{v})$ and stored for subsequent analysis of sulphate by ion chromatography (Dionex Ltd, Camberley, UK).

Particle size analysis. Surface sediment to a depth of $4 \mathrm{~cm}$ was collected for particle size analysis by sieving, and sedimentation for smaller particles (Buchanan 1984). The particles were graded according to the Wentworth scale.

\section{RESULTS}

\section{Sediment characteristics}

The mean organic matter content and particle size distributions of each sediment are shown in Figs. 2 \& 3. Particle size fractions were determined according to the Wentworth scale, but are summarized in 2 fractions; sand and fine silt/clay. The surface sediment ( 0 to $5 \mathrm{~cm}$ ) at Stn 1 was coarse sand with a low organic matter content $(<1 \%)$. Each of the other sites had fine sand with higher organic matter, usually 1 to $2 \%$. Stn 3 had the highest organic content (mean 2.9\%) and highest percentage silt/clay. The sites in decreasing order of organic matter content were Stns 3, 4, 6, 5, 2 and 1 .

\section{Temperature and dissolved oxygen}

The temperature of the water immediately overlying the sediment at each site is shown in Fig. 4. Stns $1 \& 2$ in the continental coastal region and Stn 6 in the southern British coastal region had well-mixed water columns throughout the year showing a seasonal temperature variation between 7 and $18^{\circ} \mathrm{C}$. The more northerly Stns 4 \& 5 near the British coast exhibited stratified water columns during the summer and temperatures in the water immediately overlying the sediment remained between 6 and $10^{\circ} \mathrm{C}$ throughout the year. Stn 3, at a similar latitude to Stns $4 \& 5$ but in the eastern area of the central North Sea, exhibited a well-mixed water column in September 1988 but stratification was present in September 1989, indicating that the front developed in a different position in the 2 summers.

The dissolved oxygen concentration in the water immediately overlying the sediment is shown for each site in Fig. 4. The concentration at stratified Stn 3 was found to be depleted to $2.7 \mathrm{mg} \mathrm{l}^{-1}$ in September 1989, equivalent to a depletion to $27 \%$ of the concentration 
Fig. 4. Bottom water temperature (-), and dissolved oxygen concentration $(\nabla)$, at each of the stations throughout the survey period

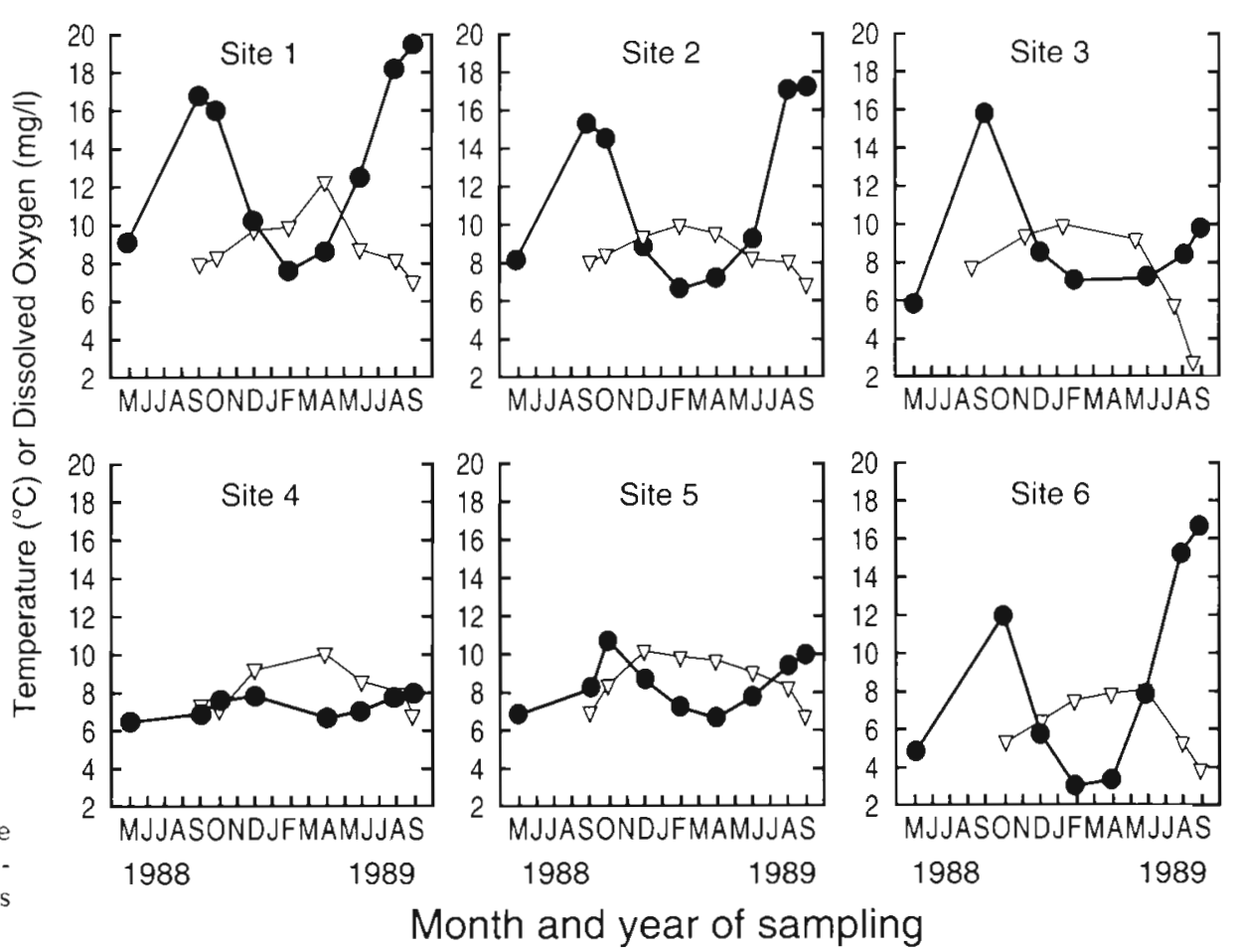

gen uptake rates. Oxygen uptake rates in winter (December 1988 to February 1989) were between 5 and $10 \mathrm{mmol} \mathrm{O}_{2} \mathrm{~m}^{-2} \mathrm{~d}^{-1}$ at all sites. In contrast, during the summer the uptake rates were found to be more variable and site dependent. Stns 2 \& 3 had marked increases in rates during the summer to between 15 and $28 \mathrm{mmol} \mathrm{O}_{2} \mathrm{~m}^{-2} \mathrm{~d}^{-1}$, compared to Stns $1 \& 6$ which only reached 7 to $15 \mathrm{mmol} \mathrm{O} \mathrm{m}^{-2} \mathrm{~d}^{-1}$. At Stns $4 \& 5$ there was little seasonal change in the rates of $\mathrm{O}_{2}$ uptake because of stratification of the water column during summer. The measured daily $\mathrm{O}_{2}$ uptake rates were integrated with respect to time to give annual $\mathrm{O}_{2}$ uptake for each of the 6 sites (Table 1). The range of annual $\mathrm{O}_{2}$ uptake rates was relatively narrow, with the highest at Stn 2 being only a factor of 1.6 higher than the lowest rate at Stn 5 .

Depth profiles of sulphate reduction showed that on average $>80 \%$ of the depth-integrated sulphate reduction over 0 to $25 \mathrm{~cm}$ occurred within the top 0 to $15 \mathrm{~cm}$ horizon (e.g. see Fig. 7). Therefore, although depth-integrated rates of sulphate reduction were only available down to $20 \mathrm{~cm}$ (Fig. 6), as this was the normal depth of sediment recovered by the corer, deeper sediments would not have made a substantial contribution to the measured rates. Rates of sulphate reduction were generally $<1 \mathrm{mmol} \mathrm{SO}_{4} \mathrm{~m}^{-2} \mathrm{~d}^{-1}$ in the winter with a small increase in the summer period. Stn 6 was rather different with winter rates of approximately $3 \mathrm{mmol} \mathrm{SO}_{4} \mathrm{~m}^{-2} \mathrm{~d}^{-1}$ which doubled during the summer. Overall, $\mathrm{O}_{2}$ uptake increased to a greater extent in the summer $(\times 2)$ than sulphate reduction $(\times 1.6)$. The ered to be part of the benthic boundary layer metabolism and hence not subtracted from the sediment oxy- 


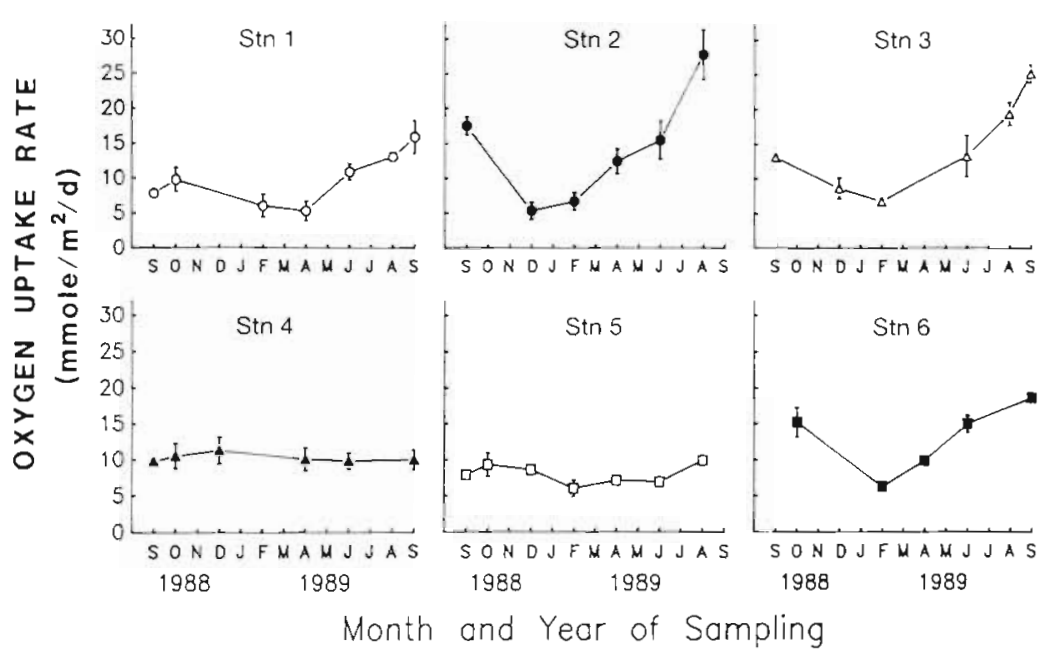

Fig. 5. Rate of benthic oxygen uptake throughout the survey period. Error bar $=1 S E, n=6$

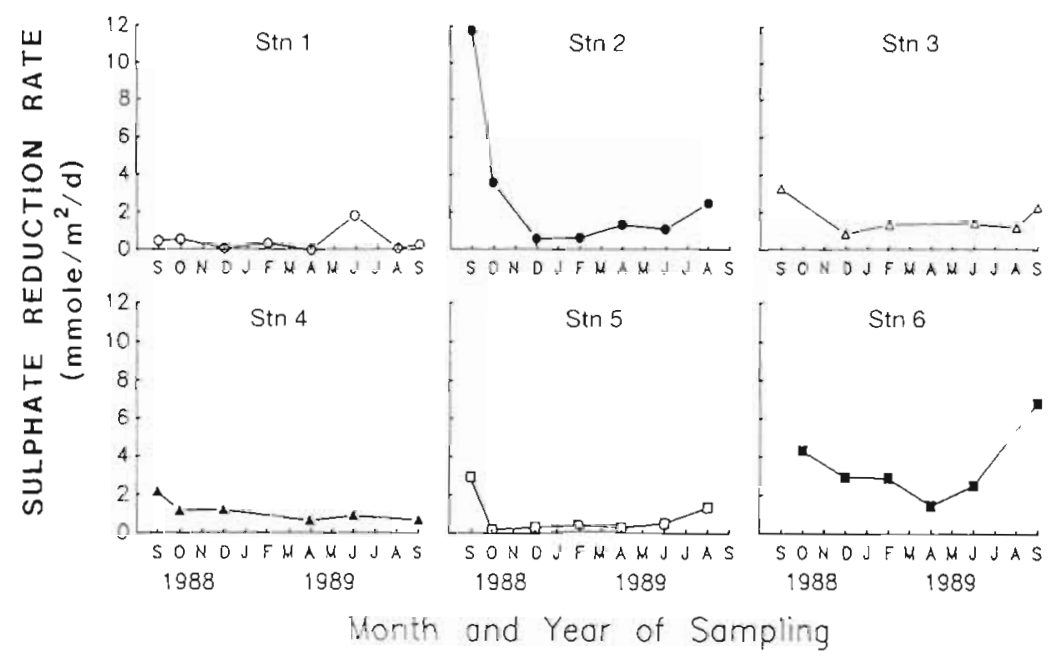

Fig. 6. Depth-integrated ( 0 to $20 \mathrm{~cm}$ ) rate of sulphate reduction at each station throughout the survey period. Standard errors fall within the symbols, $n=3$

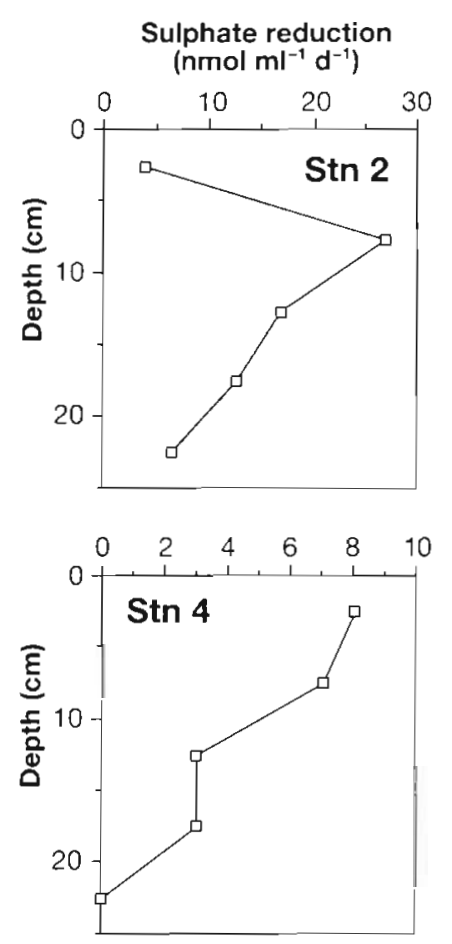

Fig. 7. Mean depth distributions of sulphate reduction rates at Stns $2 \& 4$ during the survey period

duction were much more variable than annual rates of $\mathrm{O}_{2}$ uptake: the highest rate at $\operatorname{Stn} 6$ was a factor of 9 greater than the lowest value at Stn 1.

\section{DISCUSSION}

Our data demonstrate that the North Sea bottom sediments studied were important sites of organic matter accumulation and degradation. Strus $3 \& 4$ in

highest sulphate reduction rates measured were at Stn 2 in September 1988 (11.8 mmol $\left.\mathrm{SO}_{4} \mathrm{~m}^{-2} \mathrm{~d}^{-1}\right)$, where rates were elevated at all depths but particularly at 5 to $10 \mathrm{~cm}\left(124.2 \mathrm{nmol} \mathrm{SO} \mathrm{ml}^{-1} \mathrm{~d}^{-1}\right)$. Sulphate reduction rates decreased sharply during winter at this site and began to increase again during late summer. Unfortunately, no measurement is available for September 1989. At Stns 4 \& 5 seasonal variation was limited compared to the other sites. Over $80 \%$ of sulphate reduction was to acid volatile sulphides (AVS) rather than to elemental sulphur and pyrite (PVS).

The depth-integrated values for sulphate reduction (Fig. 6) were also integrated with respect to time to yield an estimate of the annual total of sulphate reduction for each station (Table 1). These annual rates of sulphate re- the stratified region exhibited the highest organic matter contents, with greatest concentrations in the surface layers, decreasing with increased depth. This suggests that these were accumulative sites, corroborated by their higher percentage of fine silt/clay particles. Profiles of ${ }^{210} \mathrm{~Pb}$ and ${ }^{137} \mathrm{Cs}$ (Nedwell et al. 1993) confirmed that net accumulation of sediment occurred at Stns $3 \& 4$ but at other sites net accumulation of sediment could not be demonstrated. The other 4 sites, with a lower content of fine particles, had lower organic contents which tended to increase with sediment depth. The reason for this increase is unclear but it might reflect depositional changes, mixing of sedimented material by physical processes or bioturbation, changes in rates of organic matter decomposition or 
various combinations of these factors. The sedimentary organic content did not appear to be related to the rates of organic matter degradation, there being no significant correlations ( $p>0.5$ ) between sedimentary organic content and either sulphate reduction or oxygen uptake. This probably reflected differences in the relative rates of turnover of the organic inputs at each site and differences in the refractility of the organic matter remaining at each site.

In all cases appreciable rates of both aerobic and anaerobic degradation of organic matter were measured (Table 2). Van Raaphorst et al. (1990) reported $\mathrm{O}_{2}$ uptake rates during July and August 1988 averaging $12( \pm 6) \mathrm{mmol} \mathrm{O}_{2} \mathrm{~m}^{-2} \mathrm{~d}^{-1}$ for 6 stratified stations in the Dogger Bank area nearest to our Stns 3, 4 \& 5 . Their measurements compare well with the 10 to $15 \mathrm{mmol} \mathrm{O}_{2} \mathrm{~m}^{-2} \mathrm{~d}^{-1}$ determined by us for the northernmost 3 stations at the same time of the year (Fig. 5). Again, at their Stn FF, van Raaphorst et al. (1992) reported benthic $\mathrm{O}_{2}$ uptake during July and August 1989 as 32 to $40 \mathrm{mmol} \mathrm{O}_{2} \mathrm{~m}^{-2} \mathrm{~d}^{-1}$, which is similar to our rate at the nearby $\operatorname{Stn} 2$ of $28 \mathrm{mmol} \mathrm{O}_{2} \mathrm{~m}^{-2} \mathrm{~d}^{-1}$ at the same time of the year. Cramer (1990) reported a winter rate at Stn FF of $5 \mathrm{mmol} \mathrm{O}_{2} \mathrm{~m}^{-2} \mathrm{~d}^{-1}$ which is similar to our measured rate at Stn 2 during winter.

There are no data available for sulphate reduction rates in the North Sea proper although Jørgensen \& Revsbech (1989) reported sulphate reduction rates varying between 0.08 and $6.9 \mathrm{mmol} \mathrm{SO}_{4} \mathrm{~m}^{-2} \mathrm{~d}^{-1} \mathrm{dur}-$ ing July and August for sediments ranging in depth from 14 to $200 \mathrm{~m}$ water depth across the Baltic-North Sea transition zone and rates of oxygen uptake of 8.1 to $22.7 \mathrm{mmol} \mathrm{O}_{2} \mathrm{~m}^{-2} \mathrm{~d}^{-1}$. For the same transition zone, Jørgensen et al. (1990) reported sulphate reduction rates during July 1979 of 2.4 to $7.9 \mathrm{mmol} \mathrm{SO}_{4} \mathrm{~m}^{-2} \mathrm{~d}^{-1}$, although in both of these studies only sulphate reduced to AVS was measured and they did not also measure PVS as we did in our study. The range of sulphate reduction for our sites at the same time of year was 0.054 to $2.5 \mathrm{mmol} \mathrm{SO}_{4} \mathrm{~m}^{-2} \mathrm{~d}^{-1}$, and less than $20 \%$ was due to PVS. Taking into account only AVS (range

Table 2. Mineralisation of organic matter by aerobic and sulphate respiration in bottom sediments at each site in the North Sea

\begin{tabular}{|ccrcc|}
\hline Stn & \multicolumn{2}{c}{$\begin{array}{c}\text { Organic degradation } \\
\left(\mathrm{mmol} \mathrm{C} \mathrm{m}^{-2} \mathrm{yr}^{-1}\right)\end{array}$} & \multicolumn{2}{c}{$\%$ due to } \\
& $\mathrm{O}_{2}$ uptake & $\mathrm{SO}_{4}$ reduction & $\mathrm{O}_{2}$ & $\mathrm{SO}_{4}$ \\
\hline 1 & 3236.3 & 346.6 & 89.3 & 10.7 \\
2 & 4583.9 & 1398.4 & 69.5 & 30.5 \\
3 & 4392.2 & 1112.6 & 74.7 & 25.3 \\
4 & 3771.7 & 699.6 & 81.4 & 18.6 \\
5 & 2836.1 & 410.8 & 85.5 & 14.5 \\
6 & 4451.5 & 2365.0 & 46.9 & 53.1 \\
\hline
\end{tabular}

0.043 to $1.97 \mathrm{mmol} \mathrm{SO}_{4} \mathrm{~m}^{-2} \mathrm{~d}^{-1}$ ) suggests that while the rates of oxygen uptake (range 9.9 to $27.9 \mathrm{mmol} \mathrm{O}_{2}$ $\mathrm{m}^{-2} \mathrm{~d}^{-1}$ ) in the southern half of the North Sea that we studied were similar to those of the Baltic-North Sea transition zone, the rates of sulphate reduction were significantly lower. The Baltic-North Sea transition zone is atypical of the rest of the North Sea, however, being an area of strong deposition and silty, organic sediments where anoxic organic degradation might be expected to be more significant.

Seasonal changes in the rates of benthic oxygen uptake were particularly apparent at Stns 1, $2 \& 6$, with little seasonal change at Stns $4 \& 5$ (Fig. 5). This was probably correlated with the differences in water column depth and stratification, with strong seasonal changes of temperature occurring at the first 3 stations where the water column was usually homogeneous in a mean water depth of $35 \mathrm{~m}$. At the stratified Stns 4 \& 5 (mean water depth $72 \mathrm{~m}$ ) there was little seasonal change of bottom water temperature (Fig. 4) and the sediments and bottom water were therefore likely to be partially isolated from seasonal changes in the epilimnion. Stn 3 was shallower than Stns 4 \& 5 and was only stratified during the 1989 summer, but as there was still a strong seasonal increase in $\mathrm{O}_{2}$ uptake during this period, the sediments must have been closely coupled with changes in the surface water. Although for data from all sites there was a significant correlation between temperature and $\mathrm{O}_{2}$ uptake $(\mathrm{p}<0.02)$, and temperature and sulphate reduction $(p<0.05)$, there was considerable variability in these relationships between different sites. There were significant $(p<$ 0.05 ) relationships between temperature and both $\mathrm{O}_{2}$ uptake and sulphate reduction rates at Stn 6 ; between temperature and $\mathrm{O}_{2}$ uptake only for Stns 1, 2 \& 5; between temperature and sulphate reduction only at Stn 3; and no significant relationships between temperature and either $\mathrm{O}_{2}$ uptake or sulphate reduction for Stn 4. Presumably the significant relationship with temperature is both direct and indirect, e.g. via seasonal changes in water column productivity. A positive relationship with both $\mathrm{O}_{2}$ uptake and sulphate reduction at Stn 6 may reflect a strong coupling between water column and benthic processes, which is also consistent with the dominant role of sulphate reduction in organic matter degradation at this site (Table 2). The lack of significant relationship with temperature for the stratified Stn 4 may reflect some uncoupling between the water column and benthic processes. The remaining sites represent a situation between these 2 extremes.

Increased benthic oxygen uptake during the summer was reflected in decreases in the dissolved oxygen concentration of bottom water at all sites (Fig. 4), but most significantly at stratified Stn 3 where the dis- 
solved oxygen concentration decreased to only $42 \%$ of air saturation. Although, except for $\operatorname{Stn} 6$, this $\mathrm{O}_{2}$ depletion of bottom water seemed to be associated with only a limited increase in sulphate reduction rates (Fig. 6), when expressed relative to the low rates measured previously at each site the increases were similar $(\times 1.9)$ to the increase of $\mathrm{O}_{2}$ uptake during the same period $(\times 1.3)$.

Total organic carbon mineralisation was calculated stoichiometrically from the measured $\mathrm{O}_{2}$ uptake, assuming that sulphide was reoxidised within the surface oxic layer of sediment and therefore contributed to $\mathrm{O}_{2}$ uptake rate, and that there was a $1: 1$ ratio between $\mathrm{O}_{2}$ uptake and organic matter oxidation to $\mathrm{CO}_{2}$ (Jørgensen 1983). The contribution of anaerobic sulphate reduction to organic matter degradation was calculated from the 1:2 stoichiometry between sulphate reduction and organic carbon, and the estimate of the total organic carbon mineralization (Jørgensen 1983). On an annual basis benthic organic matter mineralisation was dominated by aerobic metabolism (Table 2), sulphate reduction accounting for between 11 and $53 \%$ of the total. The smallest proportion of sulphate reduction was at Stn 1, where the large amount of coarse sand (44\%) and low organic content presumably facilitated oxygen penetration into the sediment and maximised the aerobic layer. Conversely, the largest proportion of detrital degradation driven by sulphate reduction $(53 \%)$ was at Stn 6 which was predominantly fine sand $(88 \%)$ with a higher organic content. Concurrently with our study, Joint and coworkers (I. Joint pers. comm.) measured primary production at or near 5 of our 6 stations. Table 3 shows their estimates of annual net primary production (NPP), together with our estimates of benthic mineralisation of organic carbon. If we ignore any effects of lateral transport to or from adjacent areas, at the 5 stations benthic mineralisation accounted for between 16.2 and $55.2 \%$ of the NPP. The smallest proportion was at Stn 1 in the turbulent, well-mixed southerly area near the English Channel mouth where

Table 3 Benthic mineralisation of organic matter as a percentage of the net primary production at each station

\begin{tabular}{|cccc|}
\hline Stn & $\begin{array}{c}\text { Primary } \\
\text { production } \\
\left(\mathrm{mol} \mathrm{C} \mathrm{m}^{-2} \mathrm{yr}^{-1}\right)\end{array}$ & $\begin{array}{c}\text { Benthic } \\
\text { mineralisation } \\
\left(\mathrm{mol} \mathrm{C} \mathrm{m}^{-2} \mathrm{yr}^{-1}\right)\end{array}$ & $\%$ \\
\hline 1 & 20.0 & 3.2 & 16.2 \\
2 & 11.6 & 4.6 & 39.5 \\
3 & 8.0 & 4.4 & 55.2 \\
4 & 9.6 & 3.8 & 39.2 \\
6 & 20.0 & 4.5 & 22.2 \\
arimary production data from 1. Joint (pers. comm.) \\
\hline
\end{tabular}

settlement might be expected to be least. The proportionate benthic remineralisation was high at the 2 stratified stations ( $3 \& 4$ ) and at Stn 2 near the Dutch coast. On the average, benthic remineralisation of organic matter was equivalent to $35.5 \%$ of the NPP in the water column, showing that the bottom sediments were important sites for organic matter degradation, and hence recycling of elements from settled biomass back to the water column.

Aletsee \& Rick (1988, cited in Kempe \& Pegler 1991) have estimated the NPP in the whole $517000 \mathrm{~km}^{2}$ of the North Sea as $150 \times 10^{6} \mathrm{t} \mathrm{C} \mathrm{yr}^{-1}$. The area of the southern half of the North Sea is approximately $2.4 \times$ $10^{11} \mathrm{~m}^{2}$ between $55^{\circ} 30^{\prime} \mathrm{N}$ and the entrance of the Dover Straits, and proportionate NPP would be equiv-

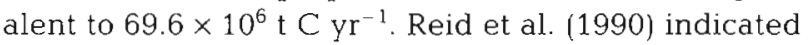
that NPP in the southern North Sea was about $200 \mathrm{~g} \mathrm{C}$ $\mathrm{m}^{-2} \mathrm{yr}^{-1}$ or ca $40 \times 10^{6} \mathrm{t} \mathrm{C} \mathrm{yr}^{-1}$ in the southern half. In a study of primary production in the southern North Sea, which was also a component of the North Sea Programme, Joint \& Pomroy (1992) measured the net annual primary production in the 6 southerly ICES boxes. When allowance was made for the proportion of the areas of the ICES boxes which corresponded to the study area of the North Sea Programme, their estimate of the total annual NPP was ca $26 \times 10^{6} \mathrm{t} \mathrm{C} \mathrm{yr}^{-1}$. Thus estimates of NPP for the southern half of the North Sea range between 26 and $69.6 \times 10^{6} \mathrm{t} \mathrm{C} \mathrm{yr}^{-1}$.

Estimates of total organic matter degradation in the bottom sediments of the southern half of the North Sea (south of $55^{\circ} 30^{\prime} \mathrm{N}$ ) can be obtained in a number of ways. If an average value for annual mineralisation at the 6 sites $\left(4.06 \pm 0.8 \mathrm{~mol} \mathrm{C} \mathrm{m}^{-2} \mathrm{yr}^{-1}\right)$ is used the total mineralisation of detrital organic carbon on an annual basis in the southern part of the North Sea is approximately $9.74 \times 10^{11} \mathrm{~mol} \mathrm{C} \mathrm{yr}^{-1}\left(1.17 \times 10^{7} \mathrm{t} \mathrm{C} \mathrm{yr}^{-1}\right)$. Alternatively, data on the types of bottom deposits in the southern bight of the North Sea are available (Anon. 1965, Veenstra 1971) and have been characterised into 6 types: mud $0.4 \%$; sand $23.0 \%$; mud/sand $21.3 \%$; sand/gravel $38.2 \%$; mud/sand/gravel $10.2 \%$; rock/ sand/gravel $6.9 \%$ (D. Hydes \& S. Thomson pers. comm.). Considering only the 5 significant areas of sediment types, Stns 2, 5 \& 6 occurred on sand; Stn 3 was on mud/sand; Stn 4 was on sand/gravel; and Stn 1 was taken as characteristic of both mud/sand/gravel and rock/sand/gravel bottoms. The annual organic matter mineralisation on each sediment bottom type was calculated from the rates at the representative stations and the area of each type of bottom in the southern bight. This gave a total annual mineralisation of $1.11 \times 10^{7} \mathrm{t} \mathrm{C} \mathrm{yr}^{-1}$ which is very similar to the figure derived from an annual rate averaged from all stations. Considering the range of the various estimates of NPP, our estimation of benthic mineralisation of organic 
matter in the southern North Sea is equivalent to 17 to $45 \%$ of the total net primary production in this area, emphasising the importance of the bottom sediments in organic matter degradation and nutrient recycling.

Acknowledgements. This paper is a contribution from the Natural Environment Research Council's North Sea Community Research Programme, and the work was funded by a research grant (GST/02/328) to D.B.N. and R.J.P. The authors thank $\mathrm{Mr} \mathrm{J}$. Watson for his invaluable assistance on the cruises, and the NERC Dunstaffnage Marine Laboratory. Oban, for use of the Multiple Corer and other facilities. The authors also acknowledge the technical support on the cruises and laboratory analyses by Miss S. Vaughan, Mr M. Rutter and Dr M. James. Our thanks also go to the officers, crew and support staff of the RRS 'Challenger'.

\section{LITERATURE CITED}

Aletsee, L., Rick, H. (1988). Teilproject G5: Phytoplankton. In: Zirkulation und Schadstoffumsatz in der Nordsee (ZISCH), Endbericht BMFT Projekt MFU 0545. Selbstverl. Inst. für Meereskunde, Univ. Hamburg, p. 236- 257

Anon. (1965). Oceanographic atlas of the north Atlantic Ocean. Section 5, Marine geology. U.S. Naval Hydrographic Office, Washington, DC, p. 71

Barnett, P. R. O., Watson, J., Connelly, D. (1984). A multiple corer for taking virtually undisturbed samples from shelf, bathyal and abyssal sediments. Oceanol. Acta 7: 399-408

Berner, R. A., Westrich, J. T. (1985). Bioturbation and the early diagenesis of carbon and sulfur. Am. J. Sci. 285: 193-206

Buchanan, J. B. (1984). Sediment analysis. In: Holme, N. A., McIntyre, A. D. (eds.) Methods for the study of benthos, International biological programme handbook number 16, 2nd edn. Blackwell Scientific Publications, Oxford, p. $41-65$

Christensen, J. P. (1989). Sulphate reduction and carbon oxidation rates in continental sediments, an examination of offshelf carbon transport. Cont. Shelf Res. 9: 223-246

Cramer, A. (1990). Seasonal variation in benthic metabolic activity in a frontal system in the North Sea. In: Barnes, M., Gibson, R. M. (eds.) Trophic relations in the marine environment. Aberdeen University Press, Aberdeen, p. $54-76$

Joint, I., Pomray, A. (1992). Phytoplankton biomass and production in the North Sea. Report of the Plymouth Marine Laboratory, Plymouth, p. 32

Jørgensen, B. B. (1978). A comparison of methods for the quantification of bacterial sulfate reduction in coastal marine sediments. 1 Measurement with radiotracer techniques. Geomicrobiol. J. 1: 11-27

Jorgensen, B. B. (1980). Mineralization and the bacterial cycling of carbon, nitrogen and sulphur in marine sedi-

This article was presented by R. M. Warwick, Plymouth, United Kingdom ments. In: Ellwood, D. C., Hedger, J. N., Latham, M. J., Lynch, J. M., Slater, J. H. (eds.) Contemporary microbial ecology. Academic Press, London, p. 239-252

Jorgensen, B. B. (1982). Mineralization of organic matter in the sea bed - the role of sulphate reduction. Nature 296: $643-645$

Jorgensen, B. B. (1983). Processes at the sediment-water interface. In: Bolin, B., Cook, R. B. (eds.) The major geochemical cycles and their interactions. John Wiley and Sons, Chichester, p. 477-515

Jorgensen, B. B., Bang, M., Blackburn, T H. (1990). Anaerobic mineralization in marine sediments from the Baltic Sea-North Sea transition. Mar. Ecol. Prog. Ser. 59: 39-54

Jørgensen, B. B., Revsbech, N. P. (1989). Oxygen uptake, bacterial distribution, and carbon-nitrogen-sulfur cycling in sediments from the Baltic Sea-North Sea transition. Ophelia 31: 29-49

Kempe, S., Pegler, K. (1991). Sinks and sources of $\mathrm{CO}_{2}$ in coastal seas: the North Sea. Tellus 43B: 224-235

Kremling, K., Wenck, A., Pohl, C. (1987). Summer distribution of dissolved $\mathrm{Cd}, \mathrm{Co}, \mathrm{Cu}, \mathrm{Mn}$ and $\mathrm{Ni}$ in central North Sea waters. Dt. hydrogr. Z. 40: 103-114

Nedwell, D. B. (1984). The input and mineralization of organic carbon in anaerobic aquatic sediments. Adv. microb. Ecol. 7: $93-131$

Nedwell, D. B., Parkes, R. J., Upton, A. C., Assinder, D. J. (1993). Seasonal fluxes across the sediment-water interface, and processes within sediments. Phil. Trans. R. Soc. Lond. A 343: 519-529

Parkes, R. J., Buckingham, W. J. (1986). The flow of organic carbon through aerobic respiration and sulphate-reduction in inshore marine sediments. In: Megusar, F., Gantar, M. (eds.) Perspectives in microbial ecology. Proc. 4th int. Symp. microb. Ecol. Slovene Society for Microbiology, Ljubljana, p. 617-624

Reid, P. C., Lancelot, C., Gieskes, W W. C., Hagmier, E., Weichert, G. (1990). Phytoplankton of the North Sea and its dynamics: a review. Neth. J. Sea Res. 26: 295-331

Revsbech, N. P., Jørgensen, B. B., Blackburn, T. H. (1980). Oxygen in the sea bottom measured with a microelectrode. Science 207: 1355-1356

Talling, J. F. (1973). The application of some electrochemical methods to the measurement of photosynthesis and respiration in fresh waters. Freshwat. Biol. 3: 335-362

van Raaphorst, W., Kloosterhuis, H. T., Berghuis, E. M., Gieles, A. J. M., Malschaert, J. F. P., van Noort, G. J. (1992). Nitrogen cycling in two types of sediments of the southern North Sea (Frisian front, Broad Fourteens): field data and mesocosm results. Neth. J. Sea Res. 28: 293-316

van Raaphorst, W., Kloosterhuis, H. T., Cramer, A., Bakker, K. J. M. (1990). Nutrient early diagenesis in the sandy sediments of the Dogger Bank area, North Sea: pore water results. Neth. J. Sea Res. 26: 25-52

Veenstra, H. J. (1971). Sediments of the southern North Sea. In: Report of the Institute of Geological Sciences, No. 70/15. HMSO, London, p. 9-23

Manuscript first received: September 25, 1992

Revised version accepted: July 26, 1993 